\title{
The association between COVID-19 data and meteorological factors in Indonesia
}

\section{Supari ( $\nabla$ supari@bmkg.go.id)}

Indonesia Agency for Meteorology, CLimatology and Geophysics (BMKG) https://orcid.org/0000-00020442-5183

\section{Danang Eko Nuryanto}

Indonesia Agency for Meteorology, CLimatology and Geophysics (BMKG)

\section{Amsari Muzakir Setiawan}

Indonesia Agency for Meteorology, CLimatology and Geophysics (BMKG)

\section{Ardhasena Sopaheluwakan}

Indonesia Agency for Meteorology, CLimatology and Geophysics (BMKG)

\section{Furqon AlFahmi}

Indonesia Agency for Meteorology, CLimatology and Geophysics (BMKG)

\section{Wido Hanggoro}

Indonesia Agency for Meteorology, CLimatology and Geophysics (BMKG)

Indra Gustari

Indonesia Agency for Meteorology, CLimatology and Geophysics (BMKG)

\section{Agus Safril}

State College of Meteorology, Climatology and Geophysics (STMKG)

\section{Rezky Yunita}

Indonesia Agency for Meteorology, CLimatology and Geophysics (BMKG)

\section{Erwin Eka Syahputra Makmur}

Indonesia Agency for Meteorology, CLimatology and Geophysics (BMKG)

\section{Yunus Swarinoto}

Indonesia Agency for Meteorology, CLimatology and Geophysics (BMKG)

\section{Research Article}

Keywords: temperature, relative humidity, weather, COVID-19, Indonesia

Posted Date: October 6th, 2020

DOI: https://doi.org/10.21203/rs.3.rs-86718/v1

License: (a) This work is licensed under a Creative Commons Attribution 4.0 International License. 



\section{The association between Covid19 data and meteorological factors in Indonesia}

3 Supari Supari ${ }^{1}$, Danang Eko Nuryanto ${ }^{2}$, Amsari Muzakir Setiawan ${ }^{1}$, Ardhasena Sopaheluwakan ${ }^{2}$, 4 Furqon Alfahmi ${ }^{3}$, Wido Hanggoro ${ }^{2}$, Indra Gustari $^{1}$, Agus Safril $^{4}$, Rezky Yunita $^{2}$, Erwin Eka Syahputra Makmur², Yunus Swarinoto ${ }^{2}$

${ }^{1}$ Center for Climate Change Information, Indonesian Agency for Meteorology Climatology and Geophysics

${ }^{2}$ Center for Research and Development, Indonesian Agency for Meteorology Climatology and Geophysics (BMKG), Jakarta, 10720, Indonesia (BMKG), Jakarta, 10720, Indonesia Jakarta, 10720, Indonesia

17 Corresponding Author:

18 Supari, Ph.D (ORCID: 0000-0002-0442-5183)

19 Division of Climate Variability Analysis

20 Centre for Climate Change Information,

21 Indonesia Agency for Meteorology, Climatology and Geophysics (BMKG)

22 Jl. Angkasa I, No 2, Kemayoran, Jakarta, Indonesia

23 Email: supari@ bmkg.go.id; supari.bmg@gmail.com 


\section{The association between Covid19 data and meteorological factors in Indonesia}

\section{Abstract}

On March 2, 2020, the first Coronavirus Disease (COVID-19) case was reported in Jakarta, Indonesia. One and half month later (15/05/2020), the cumulative number of infection cases was 16496 with a total of 1076 mortalities. This study is aimed to investigate the possible role of weather in the early cases of COVID-19 incidence in six selected cities in Indonesia. Daily data of temperature and relative humidity from weather stations nearby each city were collected during

34 the period 3 March - 30 April 2020, together with data of COVID-19 cases. Correlation tests and 35 regression analysis were performed to examine the association of those two data series. In addition, we analysed the distribution of COVID-19 with respect to weather data to estimate the effective

37 range of weather data supporting COVID-19 incidence. Our results reveal that weather data is 38 generally associated with COVID-19 incidence. The daily average temperature (T-ave) and 39 relative humidity (RH) presents significant positive and negative correlation with COVID-19 data, 40 respectively. However, the correlation coefficients are weak with the strongest correlations found 41 at 5 day lag time i.e. $0.37(-0.41)$ for T-ave $(\mathrm{RH})$. The regression analysis consistently confirmed 42 this relation. The distribution analysis reveals that the majority of COVID-19 cases in Indonesia 43 occurred in the daily temperature range of $25-31^{\circ} \mathrm{C}$ and relative humidity of $74-92 \%$. Our findings 44 suggest that COVID-19 incidence in Indonesia has a weak association with weather conditions. 45 Therefore, non-meteorological factors seem to play a larger role and should be given greater 46 consideration in preventing the spread of COVID-19. 


\section{Introduction}

The world was stirred by the spread of the Corona virus in Wuhan, China, starting in

52 January 2020, which caused local authorities to impose lockdowns in several affected cities [1-5].

53 In mid-latitude countries in the northern hemisphere (US, Italy, Spain, Iran, UK, Germany, etc.)

54 the number of patients exposed to the Corona virus Disease 2019 (COVID-19) was increasing. On

5511 March 2020, the World Health Organization (WHO) declared COVID-19 as a pandemic due to

56 its global spread [6]. Uniquely, cases in China as the country of origin COVID-19 have declined.

57 The spread of COVID-19 to tropical countries including Indonesia was also becoming increasingly

58 massive. With a total population of nearly 270 million [7], Indonesia is a vulnerable country to

59 such a fast spreading infectious disease.

60 On March 2, 2020, the Indonesian government announced the first and second cases of

61 COVID-19 infection of two Depok citizens, outside of Jakarta City [8]. The contact tracing showed

62 that transmission to those citizens occurred at an event held on February 14, 2020 in Jakarta. There

63 were foreign citizens attending the event among whom later one person was confirmed infected

64 by the disease. Four days after the first case, another case of COVID-19 was found and afterwards

65 the disease continued to spread. The development of the cumulative rate rapidly followed an

66 exponential pattern. On 15 May, the total of COVID-19 cases reported over all 34 Indonesian

67 Provinces was 16,496 with a total of 1076 mortalities

68 (https://www.worldometers.info/coronavirus/). 
The emergence of COVID-19 cases in Indonesia triggered discussions related to the risk

70 of COVID-19 transmission in tropical countries with a warm and humid climate that is very

71 different from the conditions where the disease was first found. Some previous studies revealed

72 that countries located in high altitudes with low temperatures and low humidity have a higher

73 vulnerability compared to tropical countries. They generally found that COVID-19 transmissions

74 were influenced by weather conditions such as temperature [9-15], relative humidity [13,14,16-

$7518]$ and precipitation $[19,20]$. Some of these studies indicated that ideal conditions for the corona

76 viruses are temperatures of around $8-10{ }^{\circ} \mathrm{C}$ with a relative humidity of about 60-90\% [21,22].

77 Research by Bannister-Tyrrell et al., [9] also found a negative correlation between temperature

78 (above $1^{\circ} \mathrm{C}$ ) and the estimated number of COVID-19 cases per day. They showed that COVID-

7919 had optimum dispersion at very low temperatures $\left(1-9^{\circ} \mathrm{C}\right)$. This indicates that in countries with

80 high temperatures and high humidity the risk of COVID-19 transmission is actually minimum.

81 On the other hand, the current situation shows that tropical countries are also vulnerable to

82 COVID-19 exposure. Many tropical countries currently have a high number of COVID-19

83 confirmed cases (per 15 May 2020) such as Brazil (218,223), India (85,784 cases), Ecuador

84 (31,467 cases), Singapore (26,891 cases) (https://www.worldometers.info/coronavirus/).

85 Additionally, recent publications by Auler et al., [17] and Luo et al., [23] reported COVID-19

86 cases also thrived in high temperatures, a contradictory conclusion to previous studies [21,24].

87 This discrepancy in research results suggests that the role of weather factors on COVID-19

88 transmission is still an open question and topic of debate [24,25].

89 In Indonesia, the association between weather conditions and COVID-19 cases has been

90 studied by Asyary and Veruswati, [27] and Tosepu et al., [26]. Tosepu et al., [26] found that

91 temperature significantly correlates to COVID-19 cases while Asyary et al [27] reported that 
92 sunlight exposure increased the recovery rate of COVID-19. However, the studies were done over

93 a very short period (one month) and only in one city, i.e. Jakarta. Extending those previous studies

94 in Indonesia, this study aims to comprehensively investigate the role of weather factors in the

95 incidence of COVID-19 in several cities in Indonesia. While the role of social and behavioural

96 factors have been documented considerably (see for example Lakshmi Priyadarsini and Suresh,

97 [28]), literature reporting a robust role of meteorological factors on the COVID-19 transmission,

98 particularly in tropical countries is still scarce.

99 Data and Methodology

100 Data

101 Six cities were selected for this study (See Figure 1-a) considering their cumulative

102 confirmed cases (see Figure 2), their location in the country (north-south of equator line and

103 western-eastern part of the country) to capture variations in climate (see Figure 1-b, 1-c) and the

104 distribution of cases throughout the country. Those six cities are Medan, Jakarta, Bogor, Surabaya,

105 Denpasar, and Makassar. Specifically, Medan is a representative of cities located north of the

106 equator, Bogor is a representative of cities with a relatively high elevation (colder climate) and

107 Denpasar and Makassar are representatives of the eastern part of Indonesia (Table 1). 
111 station for each city (see Table 2 ). We selected four weather variables i.e. average temperature (T-

112 ave), minimum temperature (Tmin), maximum temperature (Tmax) and average relative humidity

113 (RH). Those are variables most frequently investigated in previous COVID-19 studies

$114[19,20,29,30]$. T-ave and RH were computed from hourly observations (24 data per day). In

115 addition, we also computed the diurnal temperature range (DTR, Tmax minus Tmin) and absolute

116 humidity (AH). AH was computed following a method used by Luo et al., [23]. Different from

$117 \mathrm{RH}, \mathrm{AH}$ is a variable describing the actual amount of water vapour in the atmosphere. Previous

118 studies have shown that $\mathrm{AH}$ is more correlated to the disease compared to $\mathrm{RH}[31,32]$. To provide

119 climate background of the country, the daily mean temperature and relative humidity from

120 NCEP/NCAR Re-analysis data [33] for March-April during 1981-2010 were used.

121 Daily data of new cases of COVID-19 were gathered from each local government website

122 (see Table 2). The period of data varies depending on the timing of the first case of COVID-19

123 found in the respective city, as shown in Table 1. For Makassar city, the COVID-19 data used was

124 the total for South Sulawesi Province since data for Makassar was not available online. However,

125 we assumed that this province level data was still valid for Makassar city considering that the 126 majority of COVID-19 cases in South Sulawesi Province occurred in that city. Only days with 127 non-zero COVID-19 data were included in the analysis.

128 Method

129 A descriptive statistical analysis was performed both at city and country level (all data 130 together) to explore the characteristics of confirmed case counts and weather data. Two approaches 131 were then employed to find out the potential association between the incidence of COVID-19 and 
132 weather data i.e. correlation tests and non-linear regression analysis. The correlation test was done

133 for several options of lag time [16,30] to consider the incubation period of COVID-19, which is

134 on average around 5-6 days [34]. This lag time technique is also intended to accommodate the lag

135 effect of medical tests to confirm COVID-19 cases. It is known that COVID-19 reported on a

136 certain day might be due to transmission occurring several days before. In Indonesia, PCR testing

137 (polymerase chain reaction) usually takes several days to complete $[35,36]$ so that confirmed cases

138 are published several days after the time of infection. Our next analysis was based on the best lag

139 time identified from the correlation test (i.e. lag time with the strongest coefficient of correlation).

140 Additionally, to examine associative relationships between weather data and COVID-19 data, the

141 nonlinear regression analysis was employed following a method by Luo et al. [23]. As the last

142 step, we analysed the distribution of COVID-19 data with respect to weather data to point out a

143 possible consistent range of weather data favoured by COVID-19 incidence [37]. This was done

144 by visualizing COVID-19 data on a scatter plot and drawing the contour of $90 \%$ data density. This

145 means that the majority of COVID-19 data falls within the contour. By projecting the contour to

146 the weather data (x-axis), we were able to locate the effective range of weather data favouring the

147 COVID-19 incidence.

148 Results and Discussions

149 Results

150 Meteorological Condition

151 The climatology of temperature and relative humidity during March-April is shown in

152 Figure 1-b and 1-c. Based on NCEP/NCAR Re-analysis data, the March-April temperature in 
153 Indonesia ranges from $22-28{ }^{\circ} \mathrm{C}$ while relative humidity ranges from $70-95 \%$. Figure 3 shows the

154 boxplot that represents the descriptive statistics for daily meteorological variable and case numbers

155 of COVID-19 for each city. During March-April 2020, a large variation of the weather conditions

156 was observed in six selected cities in Indonesia. Generally, March and April are months with high

157 monthly rainfall but some parts of eastern Indonesia start to have a dry season onset. Jakarta,

158 Surabaya and Denpasar have the highest T-ave while Bogor has the lowest one among the six

159 cities. For DTR, the lowest (highest) value was found in Jakarta (Bogor). As expected, unlike T-

160 ave, the highest RH was found in Bogor while Jakarta and Surabaya share a nearly similar range

161 of RH data. For AH data, on the other hand, Medan had the highest mean and Bogor had the lowest

162 value. As shown in Figure 3, the range of AH data does not seem connected to other weather data

163 confirming its specific characteristics. In addition, we noted that Denpasar presented a narrow

164 range for T-ave, DTR and RH suggesting small variation of weather there.

165 The COVID-19 data, on the other hand, shows a large discrepancy among cities, with

166 Jakarta having the largest number of confirmed cases. Jakarta as the main international gate to the

167 country is the place where the first case of COVID-19 was found indicating the high risk of Jakarta

168 to this disease. During the study period (Table 1), there were a total of 4138 COVID-19 cases in

169 Jakarta. On average, there were approximately 75 cases of COVID-19 per day in Jakarta, and less

170 than 50 cases per day in other cities. With a population of 11 million, Jakarta is the centre of

171 national transmission of COVID-19 and early cases in other cities were mostly related to events in

172 Jakarta. 
The correlation of the weather variables and COVID-19 data is presented in Figure 4.

175 Except for $\mathrm{AH}$, weather variables show statistically significant correlation for all lag times. Our

176 test found that T-ave is positively correlated with COVID-19 cases even though the coefficient

177 correlation $(r)$ is weak with the highest $r$ value of 0.37 found for 1 and 5 days lag time. In contrast,

178 DTR and RH present a significantly negative correlation with relatively similar $\mathrm{r}$ values. The

179 strongest correlation for DTR was found for 8 days lag time $(r=-0.39)$ and that for RH was found

180 for 5 days lag time $(r=-0.41)$. On the other hand, AH shows the weakest correlation to the COVID-

18119 data, with $r$ values ranging from -0.03 to 0.05 . Based on the T-ave and RH data, it was observed

182 that the strongest correlation was found for 5 days lag time. This lag time probably indicates the

183 average incubation period of COVID-19 in Indonesia and this is in agreement with the WHO

184 statement about this matter [34]. Another possibility is that this 5 days lag time may represent the

185 average interval between timing of infection and diagnosis by PCR test. However, when looking

186 at each city (Table 3, Supplementary Material), the $r$ value and the lag time having the strongest

187 correlation vary among cities.

The results of a nonlinear regression analysis between weather variables and COVID-19

190 data on 5 days lag time are visualized in Figure 5. In general, the coefficient of determination $\left(R^{2}\right)$

191 for all variables is less than $20 \%$, indicating that only a small part of variance of COVID-19 data

192 can be explained by weather variability. However, considering the statistically significant

193 correlation between those two data, it is worth discussing the characteristics of COVID-19 data

194 with respect to the range of weather data in this study. 
As shown in Figure 5, the plot suggests that the confirmed number of cases increased with an increase of temperature, in the range of $25-31^{\circ} \mathrm{C}$. In contrast, in the range of $3-11^{\circ} \mathrm{C}(65-95 \%)$,

197 the confirmed cases declined as the DTR (RH) increased. On the other hand, the AH presents a 198 different pattern of relationships with more confirmed cases found at the $\mathrm{AH}$ of around 18-20 $199 \mathrm{~g} / \mathrm{m} 3$, the middle part of all distributions.

200 Distribution Analysis

201 To get an idea of the effective range of weather data favouring COVID-19 transmission in 202 Indonesia, we analysed the distribution of COVID-19 data with respect to T-ave, DTR, RH, and 203 AH, as shown in Figure 6. During March-April 2020, 90\% of confirmed cases in the six selected 204 cities (shown by contour on the scatter plot) occurred in the range of T-ave approximately between $20525-31^{\circ} \mathrm{C}$. Additionally, the bounds of DTR of $90 \%$ of total confirmed cases was around $4-11{ }^{\circ} \mathrm{C}$, 206 and that of RH (AH) was about 74-92\% (17-21 g/m3). Outside of those bounds, the number of 207 confirmed cases were generally low. For instance, for T-ave $>31$ or RH $<74 \%$, the number of 208 confirmed cases was minimum. These results may indicate the particular range of weather 209 conditions that favour COVID-19 incidence.

\section{Discussion}

211 This is the first time that the link between meteorological factors and COVID-19 incidence

212 in multi-cities in Indonesia has been investigated comprehensively. Our study extends the research

213 by Tosepu et al [26] which examines the correlation between weather and COVID-19 pandemic

214 in Jakarta, Indonesia. Our work also contributes to the insight into the characteristics of COVID-

21519 cases particularly in tropical climates which are still limited in the literature [17]. It is known 
216 that most of the research on the link of weather data and COVID-19 cases available in the literature

217 comes from sub-tropical countries [29,38,39].

218 We found that during the study period, the daily average temperature positively correlated

219 to the COVID-19 cases, in agreement with previous studies reported by Auler et al., [17], Liu et

220 al., [30] and Tosepu et al., [26]. In contrast, DTR and RH present a significant negative correlation

221 with COVID-19 data while AH shows an inconsistent correlation among all lag times studied. Our

222 findings on the role of T-ave and DTR are consistent with the study by Liu et al [30] who found

223 that the number of confirmed cases in China during the period of January 20th to March 2nd, 2020

224 tended to increase (decline) following an increase in temperature (DTR). It was also found in our

225 study that a lag time of 5 days presented the strongest correlation for T-ave and $\mathrm{RH}$ which probably

226 indicates the average time between exposure and diagnosis.

The link between weather data and the COVID-19 data was also confirmed by the results

228 of regression analysis with a 5-day lag time. As shown in Figure 5, we observed that the number

229 of confirmed cases increased following an increase in temperature, or the decrease of DTR and

230 RH. These findings indicate that the COVID-19 incidence may be partially affected by

231 meteorological factors. However, it is important to mention that both the coefficient correlation

232 and coefficient of determination was considerably low i.e. about -0.4 to 0.4 and less than $20 \%$,

233 respectively. This low value suggests that the effect of meteorological factors is limited and the

234 COVID-19 incidence might be largely influenced by non-meteorological factors. It seems that the

235 significant positive correlation between T-ave and COVID-19 data was found because the

236 temperature gradually increased from March to April following the seasonal change while at the

237 same time, the confirmed cases of COVID-19 increased due to the rapid spread of this disease. 
Our findings are somewhat in contrast with previous studies conducted in regions with

239 colder climates which reported that the increase in temperature could reduce COVID-19

240 transmission $[11,18]$. They, in general, found that lower temperatures favoured COVID-19 cases.

241 However, later studies in China by Liu et al., [30] and in Brazil by Auler et al., [17] reveal that the

242 increase of temperature is followed by an increase of confirmed cases and high temperature

243 supports COVID-19 transmission as well. This contradictory finding indicates that the potency of

244 high temperature and high humidity in reducing the transmission of COVID-19 might not be valid

245 for tropical regions where the average temperature and relative humidity is climatologically high.

246 For instance, the six selected cities in Indonesia during the months March and April 2020 registered

247 a daily temperature of higher than $25^{\circ} \mathrm{C}$ and a daily relative humidity of more than $65 \%$. This

248 range of weather data is beyond the effective bound for COVID-19 cases suggested by previous

249 studies [21,22]. Furthermore, our distribution analysis revealed that the majority of COVID-19

250 cases (90\% of cases) occurred within the temperature range of $25-31^{\circ} \mathrm{C}$ and $\mathrm{RH}$ range of $74-92 \%$.

251 Our results are in agreement with the study by Auler et al., [17] who found that the COVID-19

252 transmission rate in Brazil was initially observed to be favoured by higher mean temperatures (27.5

$253{ }^{\circ} \mathrm{C}$ ) as well as intermediate relative humidity (near $80 \%$ ).

254 We emphasize that this study presenting a preliminary analysis and the investigation was

255 limited to meteorological factors. A longer study period and more sampling of affected cities might

256 better represent the association between meteorological conditions and COVID-19 incidence. It

257 has been reported that, besides being influenced by meteorological factors, the number of

258 confirmed COVID-19 cases in a country depends on multiple factors including the extent of testing

259 conducted [40], population [19,29], social dynamics/migration scale [10,41,42], governmental

260 policies such as the limitation of public transport $[38,43,44]$ etc. In Indonesia, the number of daily 
261 confirmed cases at national level is closely correlated with the extent of testing conducted with a

262 coefficient correlation of 0.71 suggesting that the detected confirmed cases depend largely on the

263 extent of testing conducted by the government (Figure 7).

\section{Conclusions}

265 Our study demonstrates that weather conditions are weakly associated with the COVID-19

266 incidence particularly in the six selected cities in Indonesia. This is the first comprehensive

267 research that has attempted to explore the effects of meteorological factors on the COVID-19 cases

268 in multi-locations in Indonesia, an example of a country with a tropical climate. Daily mean

269 temperature (diurnal range of temperature and relative humidity) present statistically positive

270 (negative) significant correlation to confirmed COVID-19 cases. During the selected study period,

271 March-April 2020, the majority of COVID-19 incidence in Indonesia was observed to occur in the

272 daily temperature range of $25-31^{\circ} \mathrm{C}$ and relative humidity of $74-92 \%$. However, it should be noted

273 that the effect of meteorological factors is limited, considering the low value of coefficient

274 correlation and coefficient of determination presented in this study. Thus, non-meteorological

275 factors have to be considered to have more control over the COVID-19 pandemic.

\section{Declaration}

\section{Funding :}

278 Not applicable 
280 The authors declare that they have no known competing interests or personal relationships that

281 could have appeared to influence the work reported in this paper.

282 Availability of data and material (data transparency)

283 Not applicable

284 Code availability (software application or custom code)

285 Not applicable

286 Authors' contributions

287 Supari and D.E. Nuryanto contributed equally as the main contributor of this paper. All authors

288 were involved in reviewing and editing the original manuscript.

289

290 Reference

291 1. Li H, Liu SM, Yu XH, Tang SL, Tang CK: Coronavirus disease 2019 (COVID-19):

292 current status and future perspectives. International Journal of Antimicrobial Agents

$2932020, \mathbf{5 5}: 105951$.

294 2. Harapan H, Itoh N, Yufika A, Winardi W, Keam S, Te H, Megawati D, Hayati Z, Wagner AL, Mudatsir M: Coronavirus disease 2019 (COVID-19): A literature review. Journal of Infection and Public Health 2020, 13:667-673.

3. Wang L, Wang Y, Ye D, Liu Q: Review of the 2019 novel coronavirus (SARS-CoV-2) based on current evidence. International Journal of Antimicrobial Agents 2020, doi:10.1016/j.ijantimicag.2020.105948.

4. Li Q, Guan X, Wu P, Wang X, Zhou L, Tong Y, Ren R, Leung KSM, Lau EHY, Wong JY, et al.: Early transmission dynamics in Wuhan, China, of novel coronavirus-infected 
pneumonia. New England Journal of Medicine 2020, 382:1199-1207.

5. Tu H, Tu S, Gao S, Shao A, Sheng J: Current epidemiological and clinical features of COVID-19; a global perspective from China. Journal of Infection 2020, 81:1-9.

6. WHO: WHO Director-General's opening remarks at the media briefing on COVID19. World Health Organization 2020 ,

7. Kompas: Jumlah Penduduk Indonesia 2020. Kompas.com 2020,

8. The Jakarta Post: BREAKING: Jokowi announces Indonesia's first two confirmed COVID-19 cases. WwwThejakartapostCom 2020,

9. Bannister-Tyrrell M, Meyer A, Faverjon C, Cameron A: Preliminary evidence that higher temperatures are associated with lower incidence of COVID-19, for cases reported globally up to 29th February 2020. medRxiv preprint 2020, doi:doi: https://doi.org/10.1101/2020.03.18.20036731.

10. O'Reilly KM, Auzenbergs M, Jafari Y, Liu Y, Flasche S, Lowe R: Effective transmission across the globe: the role of climate in COVID-19 mitigation strategies. The Lancet Planetary Health 2020, 4:e172.

11. Holtmann M, Jones M, Shah A, Holtmann G: Low ambient temperatures are associated with more rapid spread of COVID-19 in the early phase of the endemic. Environmental Research 2020, 186:109625.

12. Xie J, Zhu Y: Association between ambient temperature and COVID-19 infection in 122 cities from China. Science of the Total Environment 2020, 724:138201.

13. Nazari Harmooshi N, Shirbandi K, Rahim F: Environmental Concern Regarding the Effect of Humidity and Temperature on SARS-COV-2 (COVID-19) Survival: Fact or Fiction. Environmental Science and Pollution Research 2020, doi:https://doi.org/10.1007/s11356-020-09733-w.

14. Scafetta N: Distribution of the SARS-CoV-2 pandemic and its monthly forecast based on seasonal climate patterns. International Journal of Environmental Research and Public Health 2020, 17:1-34.

15. Monami M, Silverii A, Mannucci E: Potential Impact of Climate on Novel Corona Virus (COVID-19) Epidemic. Journal of occupational and environmental medicine 2020, 62:371-372.

16. Wu Y, Jing W, Liu J, Ma Q, Yuan J, Wang Y, Du M, Liu M: Effects of temperature and humidity on the daily new cases and new deaths of COVID-19 in 166 countries. Science of the Total Environment 2020, 729:1-7.

17. Auler AC, Cássaro FAM, da Silva VO, Pires LF: Evidence that high temperatures and intermediate relative humidity might favor the spread of COVID-19 in tropical climate: A case study for the most affected Brazilian cities. Science of the Total Environment 2020, 729:139090.

18. Wang J, Tang K, Feng K, Lv W: High Temperature and High Humidity Reduce the Transmission of COVID-19. SSRN Electronic Journal 2020, doi:10.2139/ssrn.3551767.

19. Ahmadi M, Sharifi A, Dorosti S, Jafarzadeh Ghoushchi S, Ghanbari N: Investigation of effective climatology parameters on COVID-19 outbreak in Iran. Science of the Total Environment 2020, 729.

20. Sobral MFF, Duarte GB, da Penha Sobral AIG, Marinho MLM, de Souza Melo A: Association between climate variables and global transmission oF SARS-CoV-2. Science of the Total Environment 2020, 729:138997.

21. Chen B, Liang H, Yuan X, Hu Y, Xu M, Zhao Y, Zhang B, Tian F, Zhu X: Roles of 
meteorological conditions in COVID-19 transmission on a worldwide scale. medRxiv 2020, doi:10.1101/2020.03.16.20037168.

22. Sajadi MM, Habibzadeh P, Vintzileos A, Shokouhi S, Miralles-Wilhelm F, Amoroso A: Temperature, humidity, and latitude analysis to predict potential spread and seasonality for COVID-19. 2020.

23. Luo W, Majumder MS, Liu D, Poirier C, Mandl KD, Lipsitch M, Santillana M: The role of absolute humidity on transmission rates of the COVID-19 outbreak. medRxiv 2020, doi:10.1101/2020.02.12.20022467.

24. Quraishi SA, Berra L, Nozari A: Indoor temperature and relative humidity in hospitals: Workplace considerations during the novel coronavirus pandemic. Occupational and Environmental Medicine 2020, 77:508.

25. Yuan S, Jiang SC, Li ZL: Do Humidity and Temperature Impact the Spread of the Novel Coronavirus? Frontiers in Public Health 2020, 8:8-11.

26. Tosepu R, Gunawan J, Effendy DS, Ahmad LOAI, Lestari H, Bahar H, Asfian P: Correlation between weather and Covid-19 pandemic in Jakarta, Indonesia. Science of the Total Environment 2020, 725.

27. Asyary A, Veruswati M: Sunlight exposure increased Covid-19 recovery rates: A study in the central pandemic area of Indonesia. The Science of the total environment 2020, 729:139016.

28. Lakshmi Priyadarsini S, Suresh M: Factors influencing the epidemiological characteristics of pandemic COVID 19: A TISM approach. International Journal of Healthcare Management 2020, 13:89-98.

29. Briz-Redón Á, Serrano-Aroca Á: A spatio-temporal analysis for exploring the effect of temperature on COVID-19 early evolution in Spain. Science of the Total Environment 2020, 728:138811.

30. Liu J, Zhou J, Yao J, Zhang X, Li L, Xu X, He X, Wang B, Fu S, Niu T, et al.: Impact of meteorological factors on the COVID-19 transmission: A multi-city study in China. Science of the Total Environment 2020, 726:138513.

31. Shaman J, Kohn M: Absolute humidity modulates influenza survival, transmission, and seasonality. Proceedings of the National Academy of Sciences of the United States of America 2009, 106:3243-3248.

32. Metz JA, Finn A: Influenza and humidity - Why a bit more damp may be good for you! Journal of Infection 2015, 71:S54-S58.

33. Kalnay E, Kanamitsu M, Kistler R, Collins W, Deaven D, Gandin L, Iredell M, Saha S, White G, Woollen J, et al.: The NCEP/NCAR 40-year reanalysis project. Bulletin of the American Meteorological Society 1996, 77:437-471.

34. WHO: Coronavirus Disease 2019 (COVID-19) Situation Report - 73. 2020.

35. Aditya L Djono, Lona Olavia, Dina Manafe: PCR Testing Spearhead in Fight Against Covid-19 : Siloam. Jakarta Globe 2020,

36. Empel G Van, Mulyanto J, Wiratama BS: Undertesting of COVID-19 in Indonesia : what has gone wrong? Journal of Global Health 2020, 10:19-21.

37. Bukhari Q, Jameel Y: Will Coronavirus Pandemic Diminish by Summer? SSRN Electronic Journal 2020, doi:10.2139/ssrn.3556998.

38. Jüni P, Rothenbühler M, Bobos P, Thorpe KE, Da Costa BR, Fisman DN, Slutsky AS, Gesink D: Impact of climate and public health interventions on the COVID-19 pandemic: A prospective cohort study. Canadian Medical Association Journal 2020, 
192:E566-E573.

39. Iqbal N, Fareed Z, Shahzad F, He X, Shahzad U, Lina M: The nexus between COVID-19, temperature and exchange rate in Wuhan city: New findings from partial and multiple wavelet coherence. The Science of the total environment 2020, 729:138916.

40. Rohde R: The relationship between coronavirus ( COVID-19) spread and the weather. berkeleyearth.org 2020,

41. Wilder-Smith A, Freedman DO: Isolation, quarantine, social distancing and community containment: Pivotal role for old-style public health measures in the novel coronavirus (2019-nCoV) outbreak. Journal of Travel Medicine 2020, 27:1-4.

42. Kuper-Smith BJ, Doppelhofer L, Oganian Y, Rosenblau G, Korn CW: Optimistic beliefs about the personal impact of COVID-19. PsyArXiv 2020,

43. Shen K, Yang Y, Wang T, Zhao D, Jiang Y, Jin R, Zheng Y, Xu B, Xie Z, Lin L, et al.: Diagnosis, treatment, and prevention of 2019 novel coronavirus infection in children: experts' consensus statement. World Journal of Pediatrics 2020, doi:10.1007/s12519020-00343-7.

44. Miller MJ, Loaiza JR, Takyar A, Gilman RH: Covid-19 in latin america: Novel transmission dynamics for a global pandemic? PLoS Neglected Tropical Diseases 2020, 14:3-7. 
414 List of Tables

Table 1. List of selected cities and their characteristics

\begin{tabular}{lcccc}
\hline \multicolumn{1}{c}{ CITY } & ELEVATION & NORTH-SOUTH & WEST-EAST & PERIOD OF DATA \\
\hline MEDAN & $<50 \mathrm{~m}$ & North & West & 28 March 2020-30 April 2020 \\
JAKARTA & $<10 \mathrm{~m}$ & South & West & 2 March 2020 - 30 April 2020 \\
BOGOR & $>250 \mathrm{~m}$ & South & West & 21 March 2020 - 30 April 2020 \\
SURABAYA & $<10 \mathrm{~m}$ & South & West & 23 March 2020 - 30 April 2020 \\
DENPASAR & $<100 \mathrm{~m}$ & South & East & 1 April 2020 - 30 April 2020 \\
MAKASSAR & $<25 \mathrm{~m}$ & South & East & 15 March 2020 - 30 April 2020 \\
\hline
\end{tabular}

416

Table 2. Source of weather and COVID-19 data for six selected cities

\begin{tabular}{lll}
\hline \multicolumn{1}{c}{ CITY } & SOURCE OF WEATHER DATA & \multicolumn{1}{c}{ SOURCE OF COVID-19 DATA } \\
\hline MEDAN & Kualanamu Airport Weather Station & $\underline{\text { https://covid19.pemkomedan.go.id/ }}$ \\
JAKARTA & Kemayoran Weather Station & $\underline{\text { https://corona.jakarta.go.id/id }}$ \\
BOGOR & Dramaga Climate Station & $\underline{\text { https://pikobar.jabarprov.go.id/ }}$ \\
SURABAYA & Djuanda Airport Weather Station & $\underline{\text { https://lawanCOVID-19.surabaya.go.id/ }}$ \\
DENPASAR & Ngurah Rai Airport Weather Station & $\underline{\text { https://safecity.denpasarkota.go.id/id/covid19 }}$ \\
MAKASSAR & Hasanudin Airport Weather Station & $\underline{\text { https://covid19.sulselprov.go.id/ }}$ \\
\hline
\end{tabular}




\section{List of Figures Caption}

422 Figure 1. The map showing the location of six selected Indonesian cities and its elevation (a),

423

424

425

426

427

428

429

430

431

432

433

434

435

436

437

438

439 the climatology of daily temperature (b) and relative humidity (c) for March-April based on NCEP/NCAR Re-analysis data.

Figure 2. Time series of cumulative COVID-19 cases for selected cities during 1 March - 30 April 2020.

Figure 3. The boxplot of meteorological data and new cases of COVID-19 in six selected cities.

Figure 4. The correlation between meteorological factors and new cases of COVID-19 for total (combination of six selected cities) for several options of lag times. Markers denote statistically significant correlation.

Figure 5. Non-linear regression between meteorological data and COVID-19 cases. Blue to red colour represents the timing of data from March - April 2020.

Figure 6. Scatter plot of COVID-19 data with respect to weather data. The red contour represents the $90 \%$ of COVID-19 data density indicating the majority of data. Red vertical lines are bounds of each weather variable with $90 \%$ of COVID-19 data falling within those ranges.

Figure 7. Time series of daily testing numbers taken by the government and daily new cases detected from the test. 

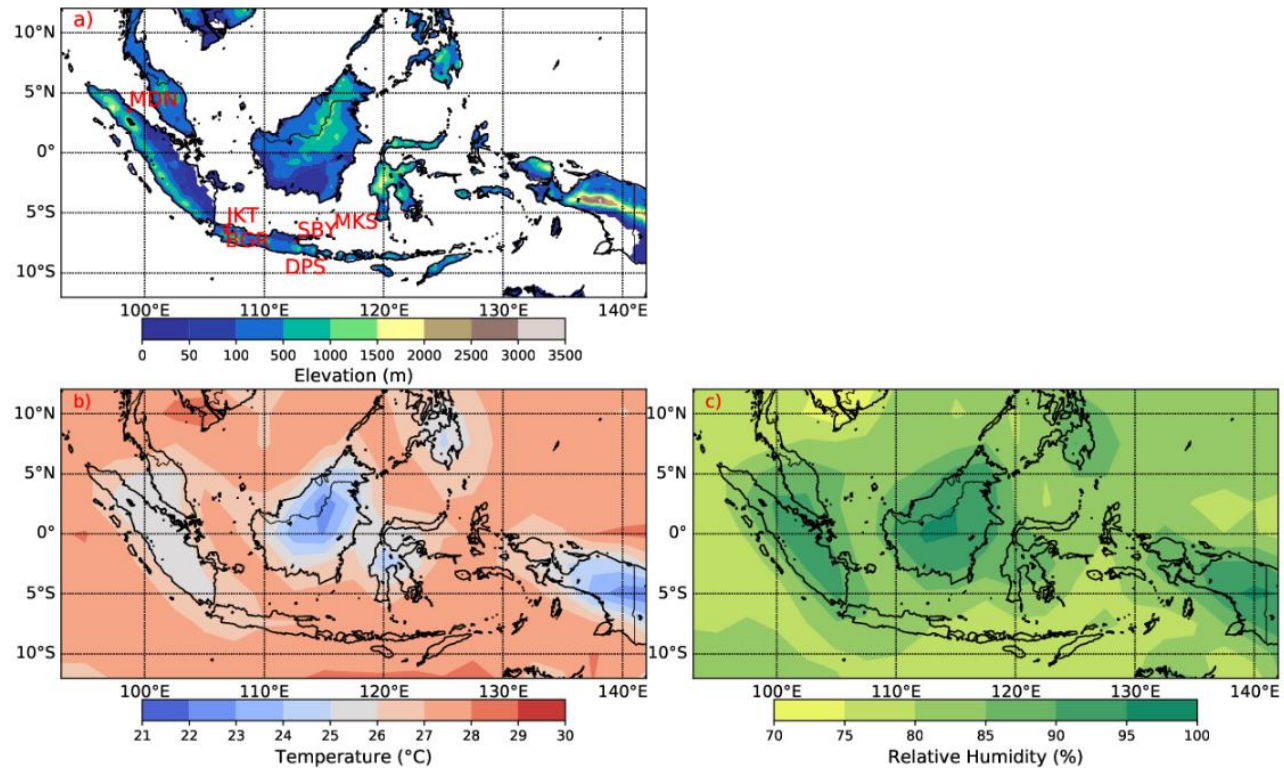

Figure 1

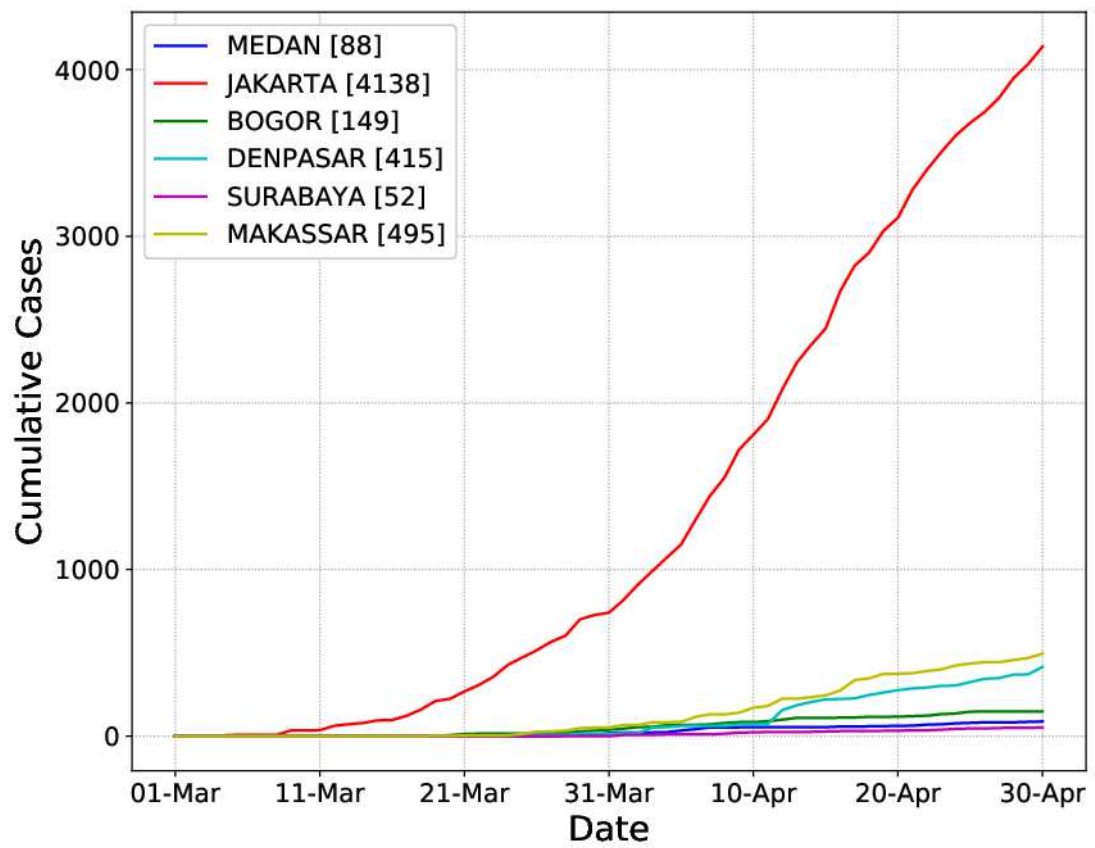

443

Figure 2 


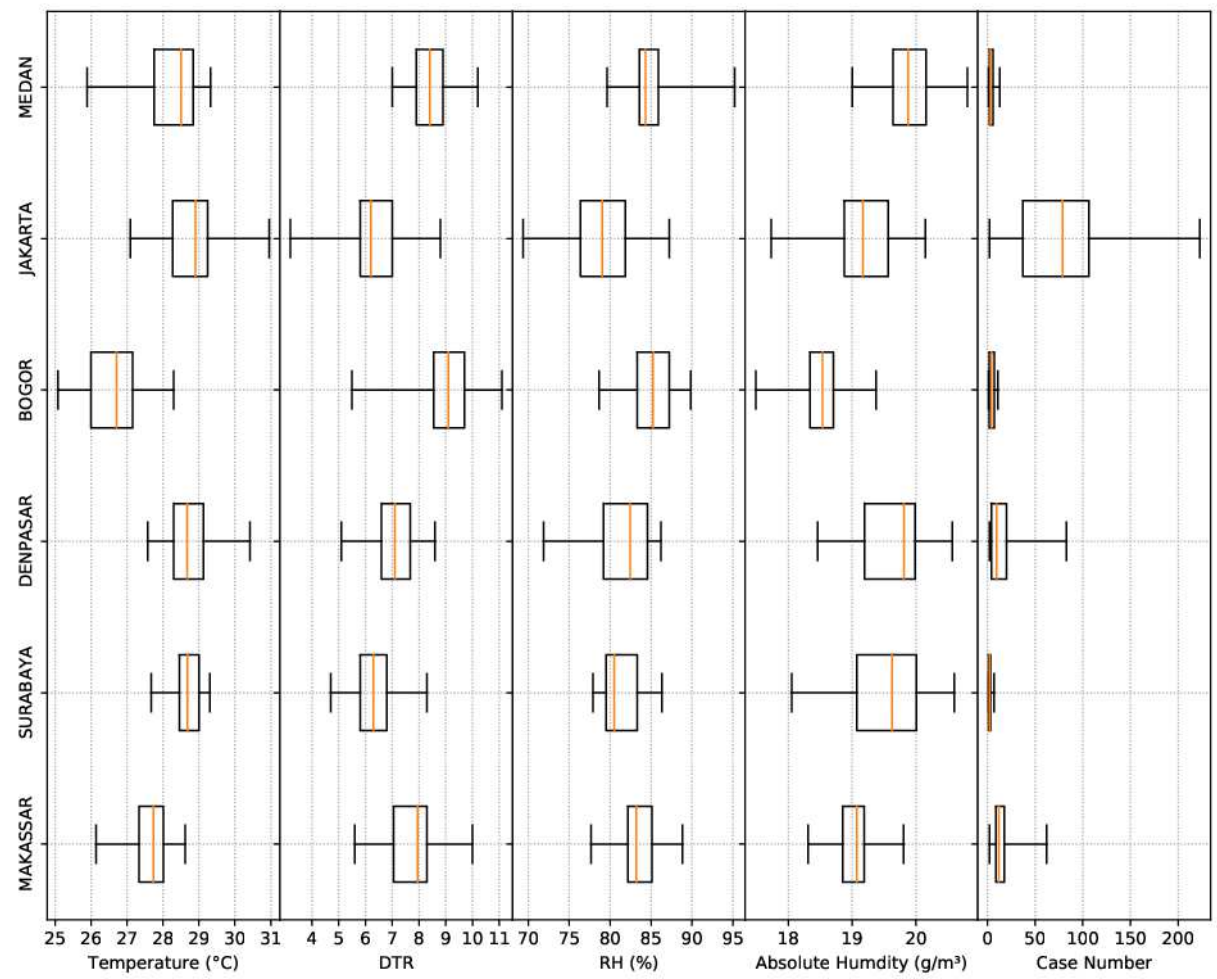

Figure 3

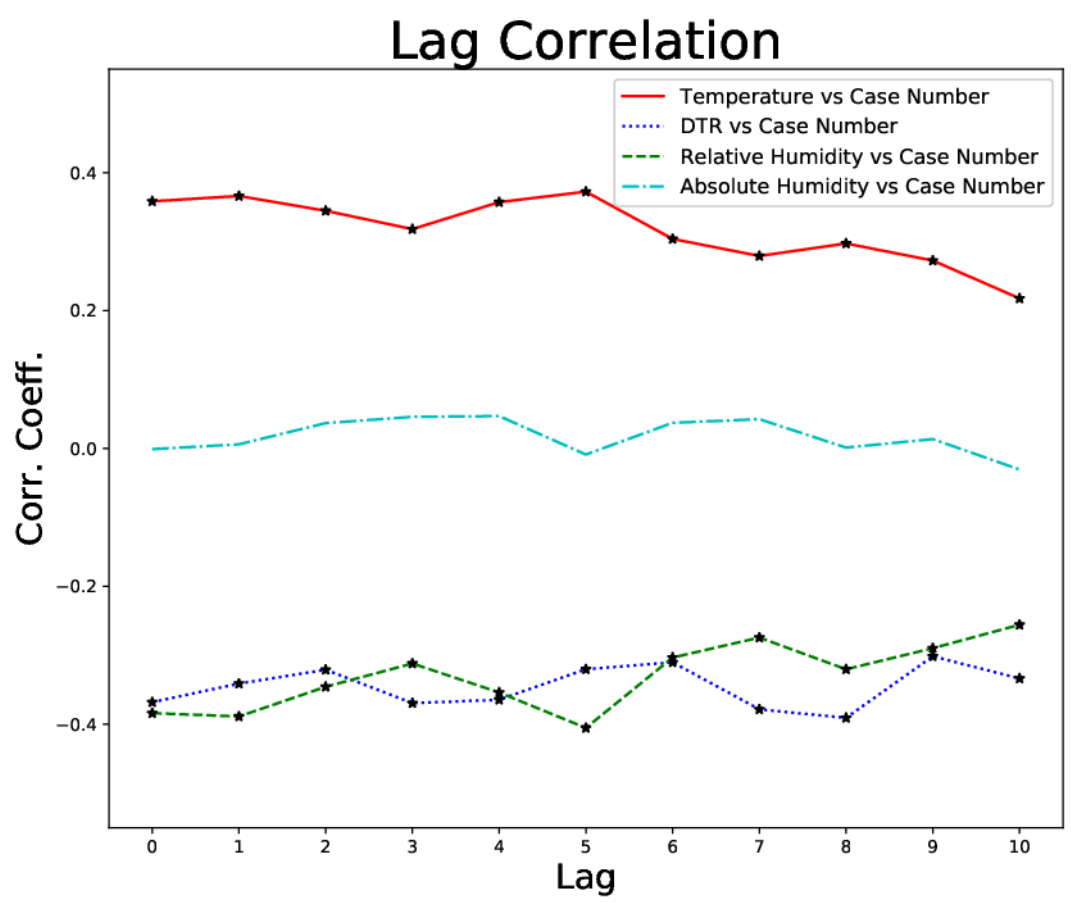

447 

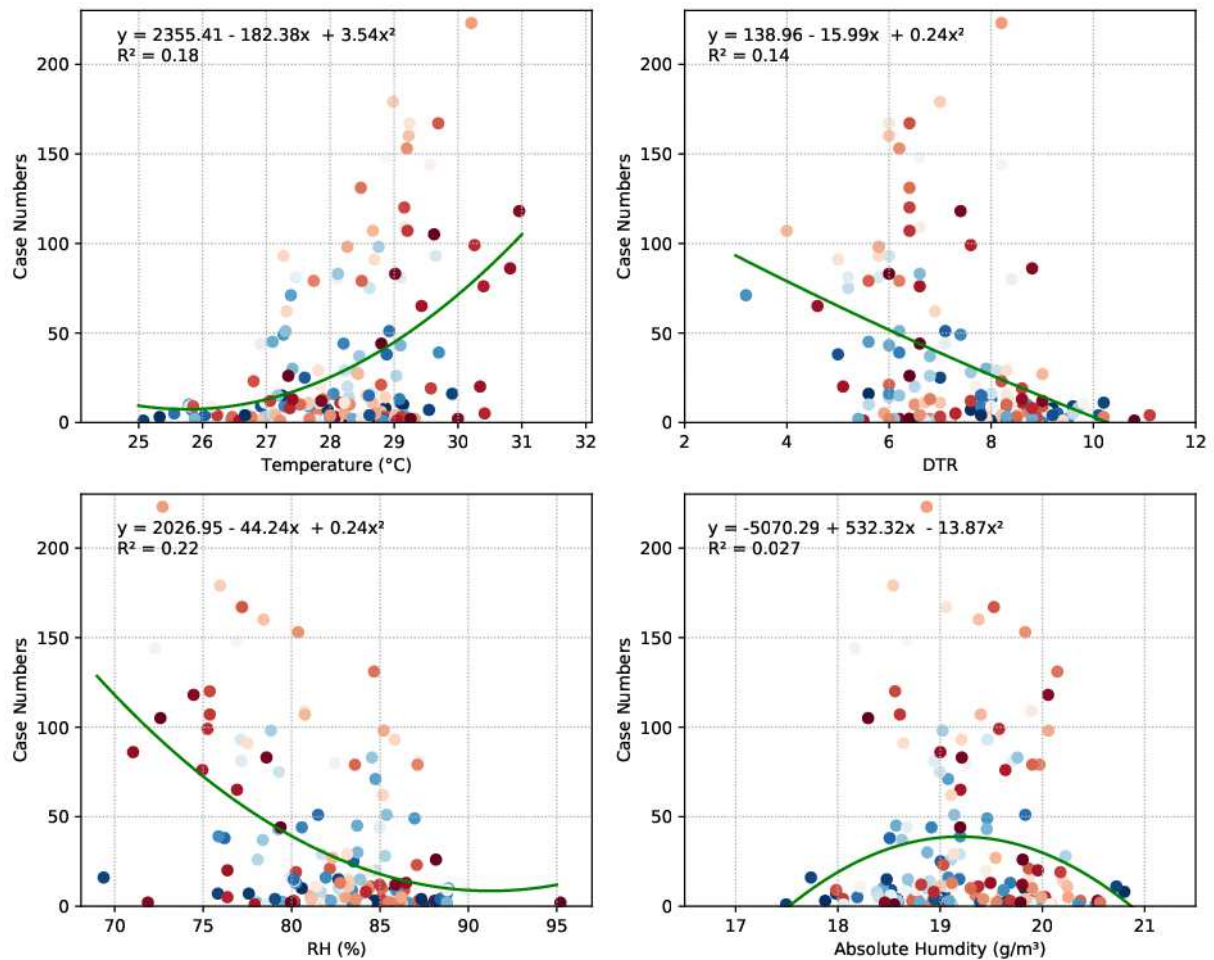

Figure 5

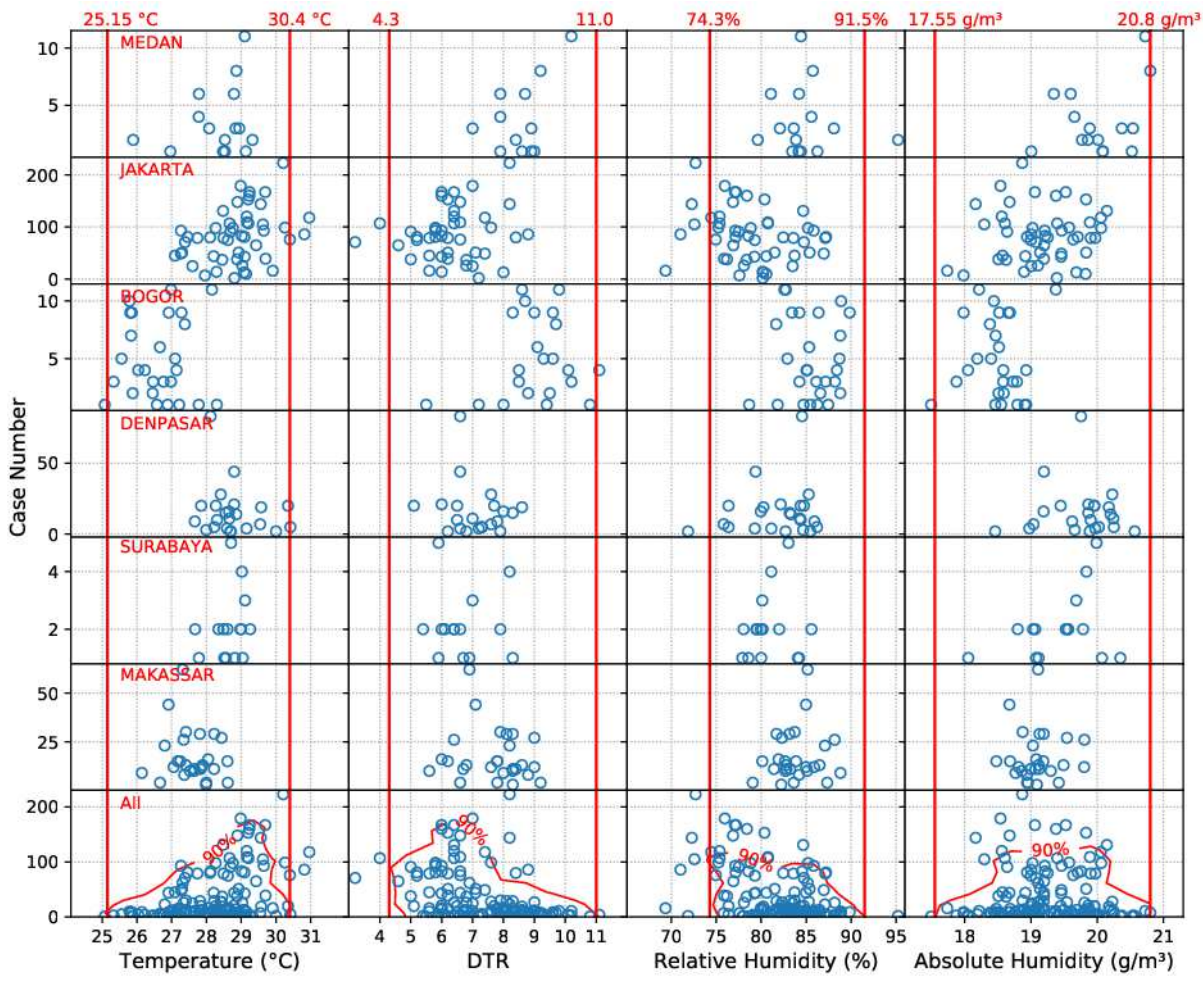




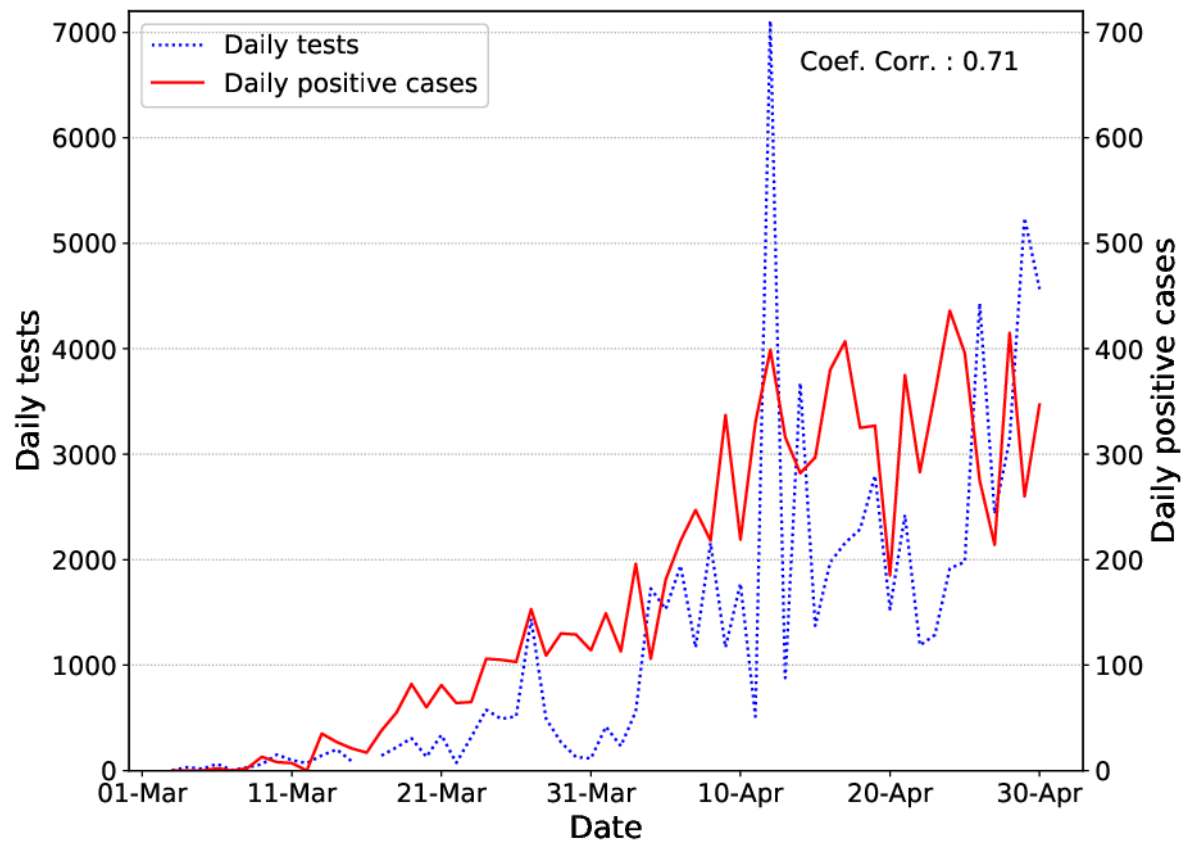

453

Figure 7

455

456 


\section{Supplementary Material}

458 Table 3. Summary of lag correlation between meteorological parameters versus new cases of COVID-19 for each city. The asterisk symbol denotes statistically significant correlation.

\begin{tabular}{|c|c|c|c|c|c|c|c|}
\hline Parameters & Lag & MEDAN & JAKARTA & BOGOR & DENPASAR & SURABAYA & MAKASSAR \\
\hline \multirow[t]{11}{*}{ Temperature } & 0 & 0.15 & 0.24 & 0.32 & -0.14 & 0.32 & -0.052 \\
\hline & 1 & -0.27 & 0.26 & 0.21 & -0.099 & 0.29 & 0.095 \\
\hline & 2 & 0.16 & 0.19 & 0.056 & -0.18 & 0.29 & 0.064 \\
\hline & 3 & -0.037 & -0.0012 & 0.27 & 0.13 & -0.019 & 0.26 \\
\hline & 4 & $0.5^{*}$ & 0.2 & -0.079 & -0.062 & -0.19 & -0.2 \\
\hline & 5 & 0.25 & $0.33^{*}$ & 0.029 & -0.2 & 0.25 & -0.12 \\
\hline & 6 & 0.34 & 0.032 & $-0.4 *$ & 0.19 & -0.048 & 0.2 \\
\hline & 7 & 0.28 & -0.016 & -0.17 & -0.13 & 0.064 & 0.14 \\
\hline & 8 & -0.47 & 0.19 & 0.059 & $0.45^{*}$ & -0.3 & $-0.41 *$ \\
\hline & 9 & 0.088 & 0.16 & 0.016 & 0.049 & $-0.72 *$ & -0.062 \\
\hline & 10 & $-0.89 *$ & 0.056 & -0.14 & 0.051 & 0.017 & -0.086 \\
\hline \multirow[t]{11}{*}{ DTR } & 0 & $0.56^{*}$ & -0.088 & 0.17 & 0.078 & 0.025 & -0.024 \\
\hline & 1 & 0.08 & 0.037 & 0.053 & 0.14 & -0.057 & -0.11 \\
\hline & 2 & -0.1 & 0.11 & $-0.49 *$ & -0.039 & 0.056 & 0.052 \\
\hline & 3 & 0.088 & -0.1 & 0.21 & -0.051 & -0.093 & 0.075 \\
\hline & 4 & 0.46 & -0.04 & -0.11 & 0.26 & -0.18 & -0.29 \\
\hline & 5 & 0.48 & 0.13 & 0.16 & -0.16 & -0.0063 & -0.16 \\
\hline & 6 & 0.2 & 0.12 & 0.35 & -0.29 & 0.46 & 0.18 \\
\hline & 7 & -0.02 & -0.13 & 0.055 & -0.11 & 0.33 & 0.014 \\
\hline & 8 & -0.35 & -0.093 & -0.3 & 0.022 & 0.19 & -0.19 \\
\hline & 9 & -0.55 & 0.095 & -0.043 & 0.38 & 0.18 & 0.058 \\
\hline & 10 & -0.57 & -0.038 & -0.28 & -0.24 & -0.21 & 0.14 \\
\hline \multirow[t]{6}{*}{ Relative Humidity } & 0 & -0.003 & -0.11 & 0.32 & -0.068 & $-0.45^{*}$ & 0.081 \\
\hline & 1 & 0.28 & -0.12 & 0.21 & 0.023 & -0.19 & -0.067 \\
\hline & 2 & 0.045 & -0.025 & 0.056 & 0.003 & -0.17 & 0.029 \\
\hline & 3 & 0.062 & 0.15 & 0.27 & -0.17 & -0.056 & -0.21 \\
\hline & 4 & -0.089 & -0.044 & -0.079 & 0.13 & 0.19 & 0.16 \\
\hline & 5 & -0.088 & -0.24 & 0.029 & 0.16 & 0.15 & 0.14 \\
\hline
\end{tabular}




\begin{tabular}{|c|c|c|c|c|c|c|c|}
\hline & 6 & -0.095 & 0.084 & $-0.4 *$ & -0.22 & 0.39 & -0.13 \\
\hline & 7 & -0.47 & 0.15 & -0.17 & 0.12 & 0.38 & -0.13 \\
\hline & 8 & 0.2 & -0.054 & 0.059 & $-0.66^{*}$ & 0.1 & 0.36 \\
\hline & 9 & -0.25 & -0.036 & 0.016 & -0.064 & -0.32 & -0.041 \\
\hline & 10 & 0.37 & -0.0019 & -0.14 & -0.065 & -0.26 & 0.0086 \\
\hline \multirow[t]{11}{*}{ Absolute Humidity } & 0 & 0.29 & 0.17 & 0.32 & -0.3 & -0.21 & 0.059 \\
\hline & 1 & -0.034 & 0.19 & 0.21 & -0.097 & 0.023 & 0.04 \\
\hline & 2 & 0.38 & 0.25 & 0.056 & -0.23 & 0.05 & 0.16 \\
\hline & 3 & 0.049 & 0.27 & 0.27 & -0.14 & -0.07 & 0.12 \\
\hline & 4 & $0.75^{*}$ & 0.23 & -0.079 & 0.15 & 0.019 & -0.091 \\
\hline & 5 & 0.34 & 0.075 & 0.029 & -0.00097 & 0.34 & 0.0094 \\
\hline & 6 & 0.33 & 0.2 & $-0.4 *$ & -0.13 & 0.34 & 0.17 \\
\hline & 7 & -0.046 & 0.24 & -0.17 & -0.018 & 0.4 & 0.074 \\
\hline & 8 & -0.44 & 0.19 & 0.059 & $-0.48^{*}$ & -0.098 & -0.3 \\
\hline & 9 & -0.1 & 0.18 & 0.016 & -0.046 & $-0.61 *$ & -0.24 \\
\hline & 10 & $-0.81 *$ & 0.068 & -0.14 & -0.046 & -0.19 & -0.2 \\
\hline
\end{tabular}



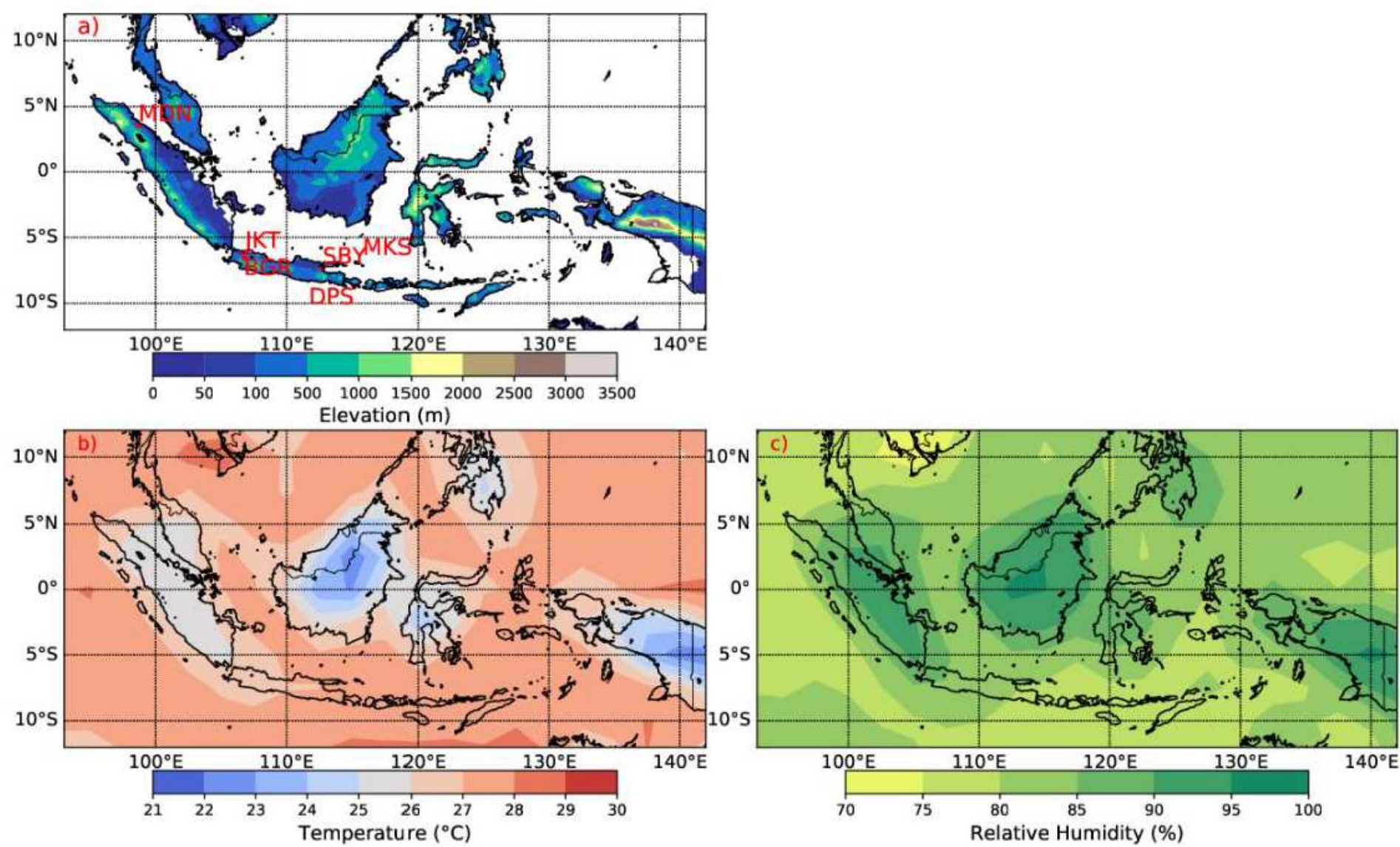

Figure 1

The map showing the location of six selected Indonesian cities and its elevation (a), the climatology of daily temperature (b) and relative humidity (c) for March-April based on NCEP/NCAR Re-analysis data. Note: The designations employed and the presentation of the material on this map do not imply the expression of any opinion whatsoever on the part of Research Square concerning the legal status of any country, territory, city or area or of its authorities, or concerning the delimitation of its frontiers or boundaries. This map has been provided by the authors. 


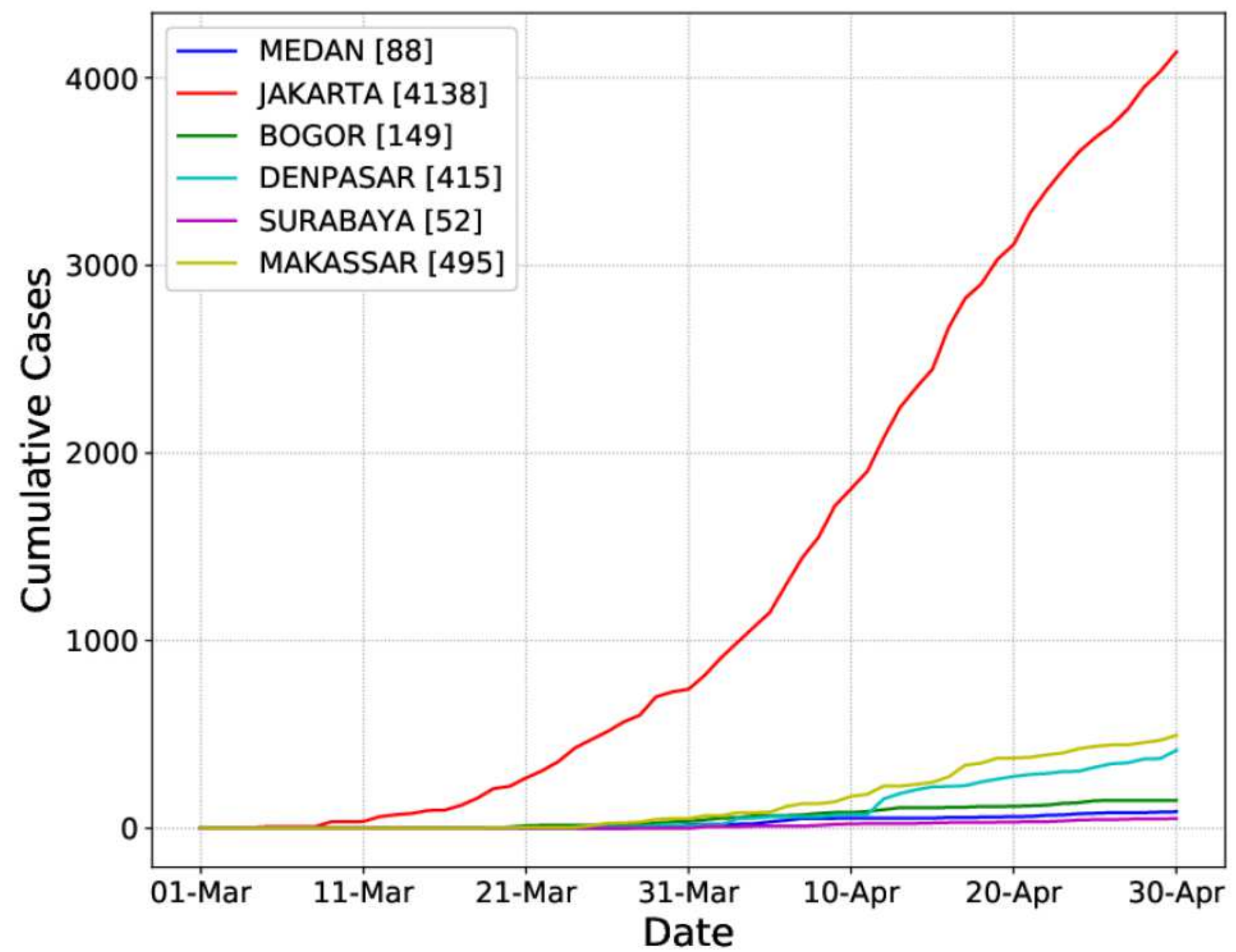

Figure 2

Time series of cumulative COVID-19 cases for selected cities during 1 March - 30 April 2020. 


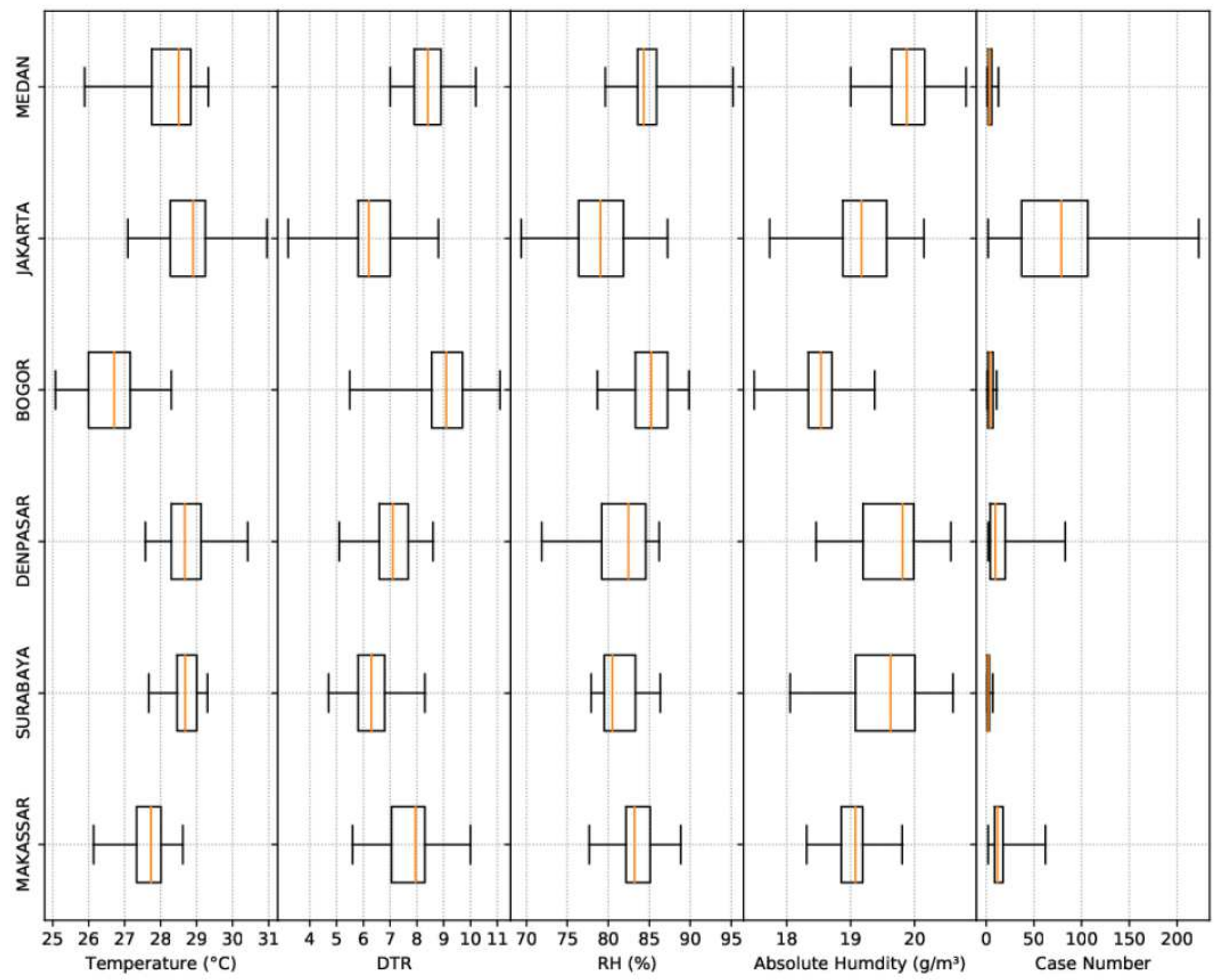

Figure 3

The boxplot of meteorological data and new cases of COVID-19 in six selected cities. 


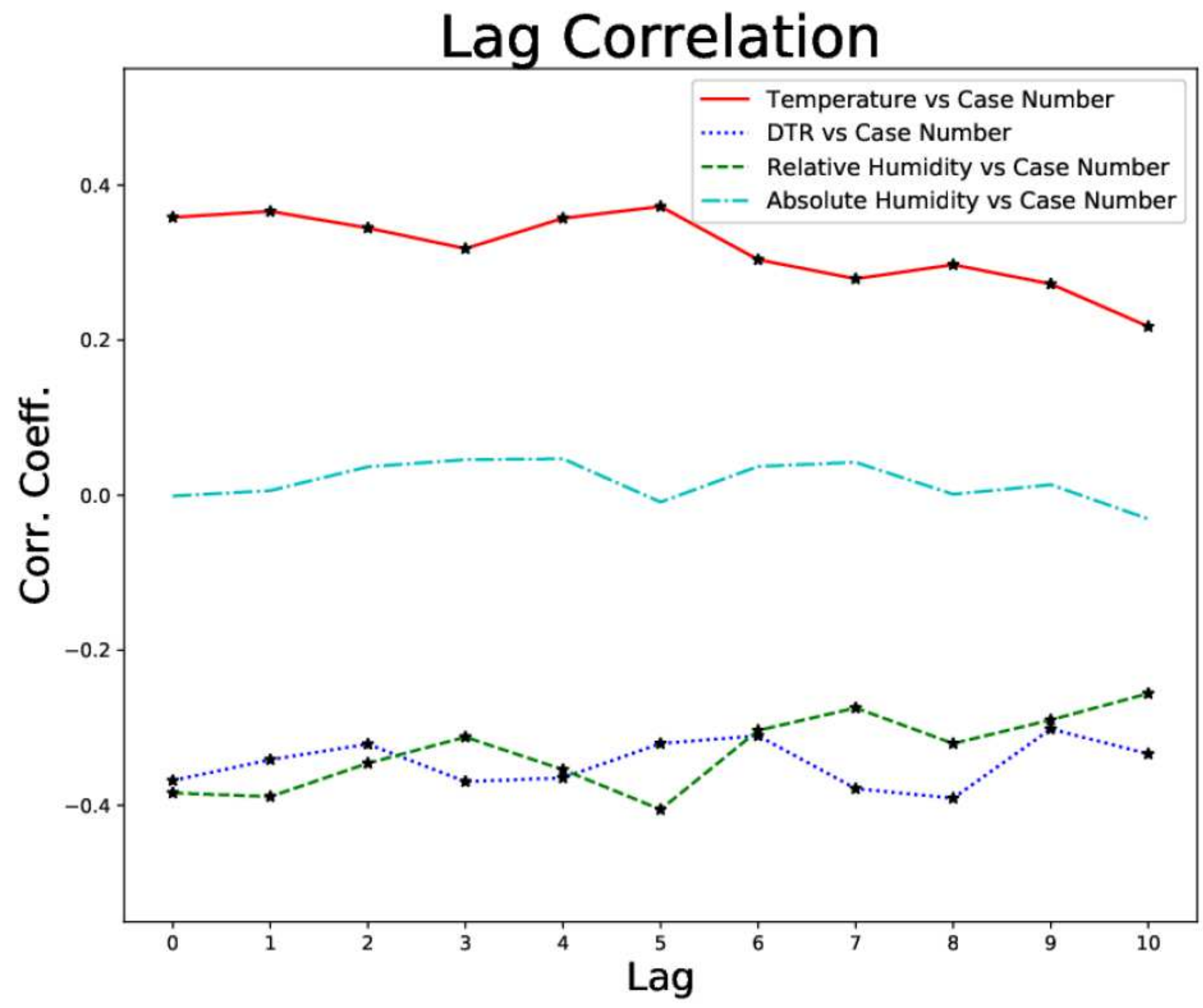

Figure 4

The correlation between meteorological factors and new cases of COVID-19 for total (combination of six selected cities) for several options of lag times. Markers denote statistically significant correlation. 

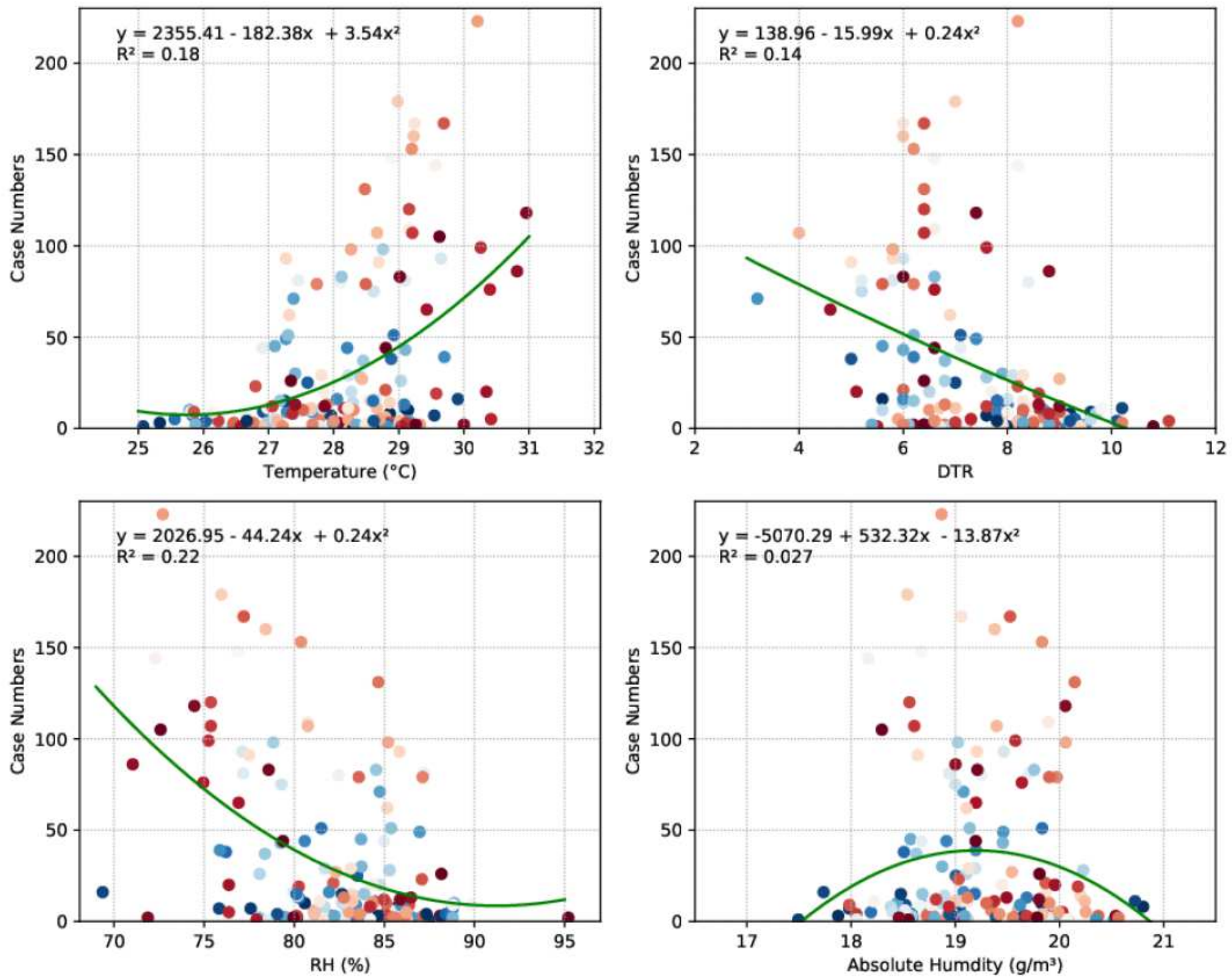

Figure 5

Non-linear regression between meteorological data and COVID-19 cases. Blue to red colour represents the timing of data from March - April 2020. 


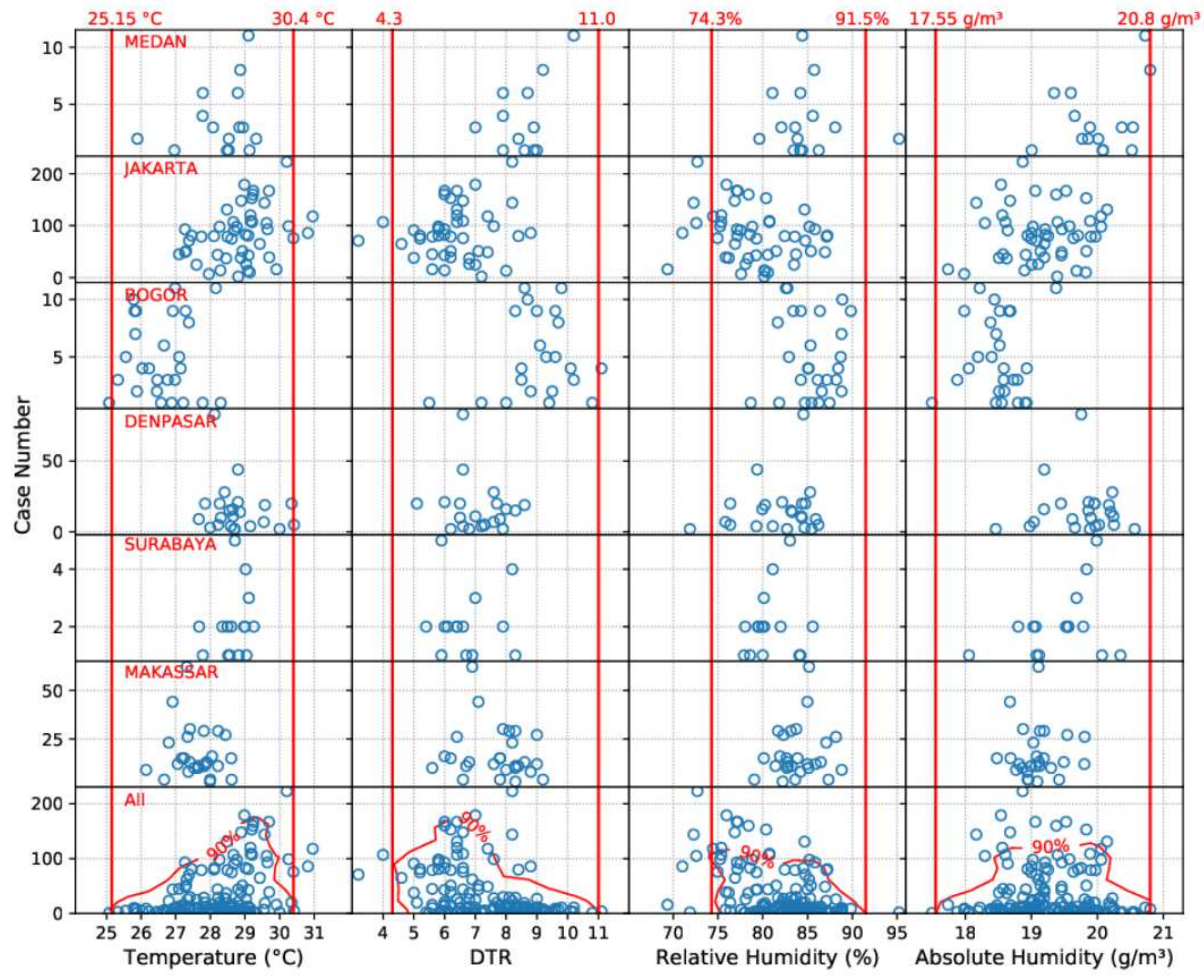

Figure 6

Scatter plot of COVID-19 data with respect to weather data. The red contour represents the $90 \%$ of COVID19 data density indicating the majority of data. Red vertical lines are bounds of each weather variable with $90 \%$ of COVID-19 data falling within those ranges. 


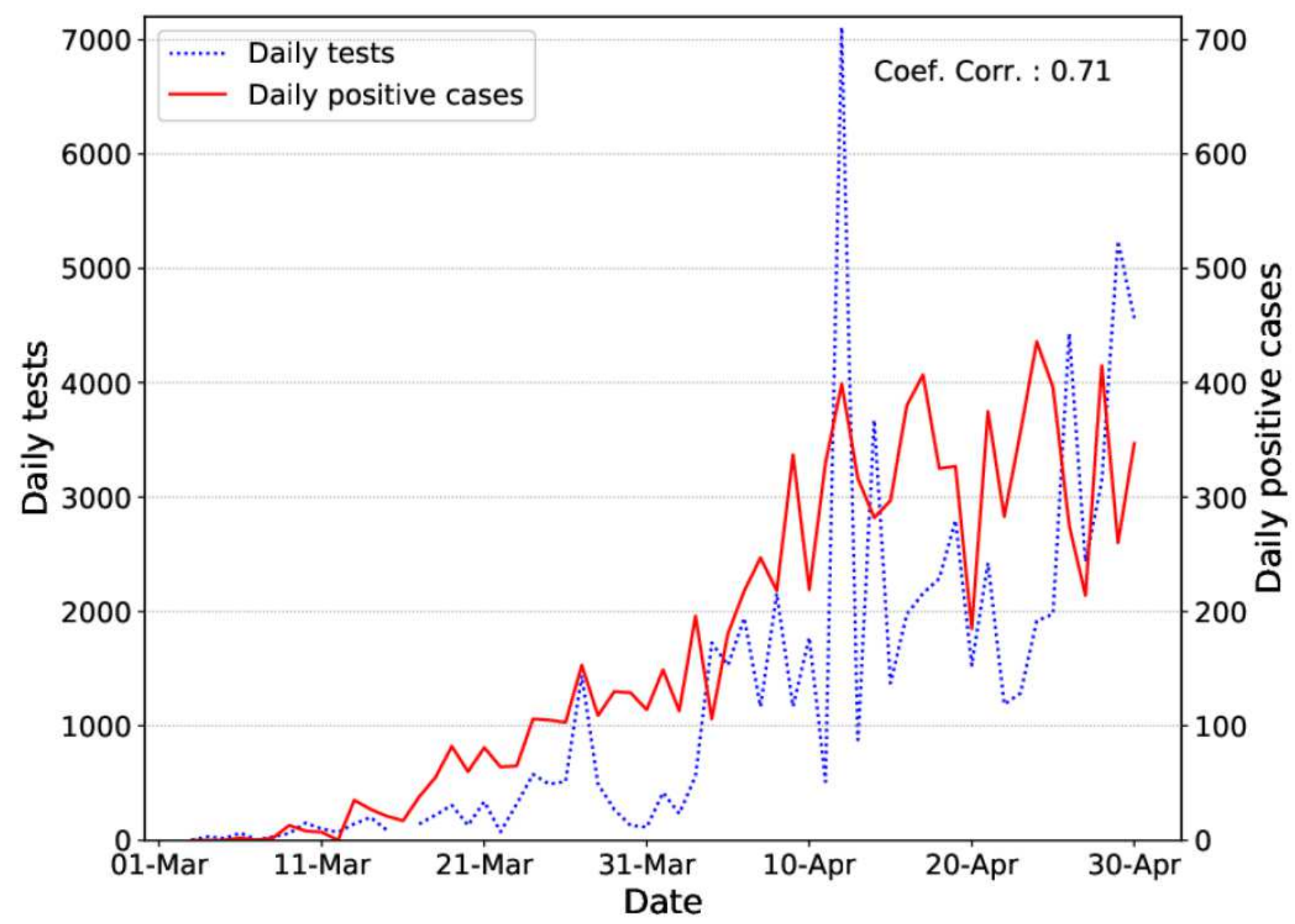

Figure 7

Time series of daily testing numbers taken by the government and daily new cases detected from the test. 